\title{
Purification and properties of cyanide hydratase from Fusarium lateritium and analysis of the corresponding chy1 gene
}

\author{
Martin J. Cluness, ${ }^{1} \dagger$ Peter D. Turner, ${ }^{2}$ Eleanor Clements, ${ }^{2}$ Denise T. Brown ${ }^{1}$ and \\ CATHERINE O'REILLY ${ }^{1 *}$ \\ ${ }^{1}$ School of Health Sciences, University of Sunderland, Wharncliffe Street, Sunderland, Tyne and Wear, UK \\ ${ }^{2}$ ICI Biological Products, Billingham, Cleveland, UK
}

(Received 9 September 1992; revised 3 March 1993; accepted 10 March 1993)

\begin{abstract}
The filamentous fungus Fusarium lateritium is cyanide tolerant, due, at least in part, to the induction by cyanide of the enzyme formamide hydrolyase (EC 4.2.1.66). This enzyme, more commonly known as cyanide hydratase, catalyses the hydration of cyanide to formamide. The enzyme was purified from $F$. lateritium and showed a subunit molecular mass of $43 \mathrm{kDa}$ (as judged by SDS-PAGE), while the native protein appeared to form aggregates of up to $1217 \mathrm{kDa}$ (as judged by gel-filtration and non-denaturing PAGE). mRNA samples from cultures grown with and without cyanide were in vitro translated and immunoprecipitated. This demonstrated that, in this species, the gene encoding the enzyme designated chy 1 , is cyanide inducible. Differential screening was used to isolate a cyanide hydratase cDNA clone which was subsequently used to obtain the corresponding genomic clone. A fragment of the cDNA clone encoding all but the first seven amino acids of the protein was expressed in $E$. coli using the expression vector pGEX-2T. Features of $\boldsymbol{F}$. lateritium cyanide hydratase together with an analysis of the nucleotide sequence encoding this enzyme are presented.
\end{abstract}

\section{Introduction}

Despite the extreme toxicity of cyanide, many microorganisms can grow in its presence either by developing a cyanide-insensitive respiratory system and/or degrading the cyanide (reviewed by Knowles, 1976, 1988). In at least one micro-organism, Pseudomonas fluorescens, cyanide can be used as the sole nitrogen source (Harris \& Knowles, 1983). Many fungi, particularly those which are pathogens of cyanogenic plants, are cyanide tolerant, and this is, at least in part, due to the presence of the enzyme formamide hydrolyase (EC 4.2.1.66), more commonly known as cyanide hydratase (Fry \& Millar, 1972). Cyanide hydratase activity appears to be correlated with the ability of some fungi to infect cyanogenic plants despite the release of hydrogen cyanide into the infection site in potentially toxic concentrations (Fry \& Munch, 1975; Fry \& Evans, 1977). In one study, fungal pathogens of cyanogenic plants were found to contain

*Author for correspondence. Tel. (091) 5152525; fax (091) 5152502.

$†$ Present address: Duphar Laboratories Ltd, Duphar House, Gaters Hill, Southampton SO3 3JD, UK.

The nucleotide sequence data reported in this paper have been submitted to GenBank and have been assigned the accession nos M99045 (genomic sequence) and M99046 (cDNA sequence). various levels of cyanide hydratase activity (Fry \& Evans, 1977). Enzyme activity in those species tested was inducible, although in some species low constitutive levels of cyanide hydratase activity were also seen. In general, lower levels of cyanide hydratase activity were seen in those species not regarded as pathogens of cyanogenic plants.

Cyanide hydratase enzyme has been studied in two phytopathogenic fungi: Gloeocercospora sorghi and Stemphylium loti (Fry \& Millar, 1972; Fry \& Munch, 1975). The enzymes appear similar, giving optimal activity in the range $\mathrm{pH} 7$ to $\mathrm{pH} 9$. The $G$. sorghi enzyme has a $K_{\mathrm{m}}$ of approximately $30 \mathrm{~mm}$-hydrogen cyanide and an estimated molecular mass of $2-10 \times 10^{6} \mathrm{Da}$.

The work presented here describes the purification and biochemical analysis of the cyanide hydratase enzyme and the cloning and sequencing of the cyanide hydratase gene from Fusarium lateritium Nees (Commonwealth Mycological Institute 300533). This species is used in the production of the cyanide-degrading product CYCLEAR by ICI Biological Products.

\section{Methods}

Microbial strains, vectors and recombinant DNA. These are listed in Table 1. 
Table 1. Microbial strains, vectors and recombinant DNA used in this study

\begin{tabular}{|c|c|c|}
\hline & Comment & Origin or reference \\
\hline F. lateritium & Wild-type Nees (CMI 300533) & $\begin{array}{l}\text { ICI Biological Products, } \\
\text { Billingham, Cleveland, UK }\end{array}$ \\
\hline E. coli $\mathrm{Y} 1088$ & Used in cDNA library construction & Young \& Davis $(1983 b)$ \\
\hline E. coli NM514 & Used in genomic library construction & Murray (1983) \\
\hline E. coli JM83 & Host for pUC plasmids/recombinants & Vieira \& Messing (1982) \\
\hline E. coli XL-1 Blue & Host for expression studies & Bullock et al. (1987) \\
\hline iNM1149 & $\lambda \mathrm{b} 538 \mathrm{srl \lambda}^{0} \lambda_{\mathrm{imm}}^{434}$ shindIII/6 ${ }^{0} \mathrm{red}^{+} \mathrm{gam}^{+}$ & Murray (1983) \\
\hline igt11 & 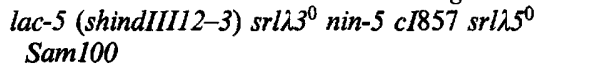 & Young \& Davis (1983a) \\
\hline pUC9 & $\mathrm{Ap}^{\mathrm{r}} \operatorname{lac} \mathbf{Z}^{\prime}$ & Vieira \& Messing (1982) \\
\hline pUC18 & $\mathrm{Ap}^{\mathrm{r}} l a c Z^{\prime}$ & Yanisch-Perron et al. (1985) \\
\hline $\mathrm{pCH} 1$ & Cyanide hydratase genomic clone & This study \\
\hline pMC211 & Cyanide hydratase cDNA clone & This study \\
\hline pMC311 & Cyanide hydratase cDNA clone (full length) & This study \\
\hline PMC312 & Truncated $\mathrm{cDNA}$ clone for expression studies & This study \\
\hline pGEX:2T & Bacterial plasmid expression vector & Pharmacia \\
\hline pGEX312 & chy 1 cDNA correct orientation for expression & This study \\
\hline pGEX313 & chy 1 cDNA incorrect orientation for expression & This study \\
\hline
\end{tabular}

Cyanide hydratase enzyme assay. Samples $(5-100 \mu l)$ were incubated in $1 \mathrm{ml} 120 \mathrm{~mm}-\mathrm{NaCN} / 100 \mathrm{~mm}$-Tris $/ \mathrm{HCl}$ buffer, $\left(\mathrm{pH} 8.5,20^{\circ} \mathrm{C}\right)$ for $15 \mathrm{~min}$. The reaction was stopped with $2 \mathrm{ml} 2.3 \mathrm{M}$-hydroxylamine and samples incubated for $7 \mathrm{~min}$ at $20^{\circ} \mathrm{C}$. After cooling on ice, $1 \mathrm{ml} 4 \mathrm{M}$ $\mathrm{HCl}$ was added followed by $1 \mathrm{ml} 1 \cdot 23 \mathrm{M}-\mathrm{FeCl}_{3} / 75 \mathrm{~mm}-\mathrm{HCl}$. Absorbance at $540 \mathrm{~nm}$ was used to estimate formamide concentration by means of a standard curve (Snell \& Snell, 1954). Activity is expressed

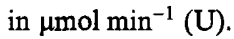

Enzyme purification. Culture was collected over a $48 \mathrm{~h}$ period from a laboratory chemostat (growth conditions as described by Richardson \& Clarke, 1987) and maintained at $4^{\circ} \mathrm{C}$. Cells were harvested by vacuum filtration through muslin, and were then washed and resuspended in $100 \mathrm{~mm}$-Tris/ $\mathrm{HCl}$ buffer (pH 8.5) containing $10 \mathrm{~mm}$ EDTA. Batches of cell suspension were mixed with glass beads $(50 \mathrm{ml}$; $1 \mathrm{~mm}$ diam.) and disrupted in a bead mill $(3 \mathrm{~min})$ at $4{ }^{\circ} \mathrm{C}$. The beads were removed and washed by decanting. The combined crude extract was centrifuged $\left(17000 \mathrm{~g}, 15 \mathrm{~min}, 4^{\circ} \mathrm{C}\right)$ to obtain the crude supernatant. Crude supernatant was stirred with $120 \mathrm{~g}$ DEAE-cellulose (equilibrated with buffer, as above) for $75 \mathrm{~min}$ at $4{ }^{\circ} \mathrm{C}$. The gel was recovered by vacuum filtration, washed with buffer, packed into a column $(5 \times 16 \mathrm{~cm})$ and eluted with a salt gradient, $0-4 \mathrm{M}-\mathrm{NaCl}$ in buffer). Active fractions were pooled to yield the DEAE eluate. The DEAE eluate was brought to $40 \%$ saturation with ammonium sulphate by addition of crystals. The supernatant was recovered by centrifugation (as above) and brought to $60 \%$ saturation. The pellet was recovered by centrifugation (as above) and resuspended in buffer. This was desalted using a Sephadex G-25 column eluted with $20 \mathrm{~mm}$ Tris/HCl buffer (pH 8.5) containing 10 mM-EDTA. The desalted $60 \%$ ammonium sulphate fraction was loaded onto an anion-exchange column (LKB FPLC system Mono Q, HR 16/10 column) and eluted with a $0-0.4 \mathrm{M}-\mathrm{NaCl}$ gradient. The active fractions were pooled and loaded onto a Sephacryl S-400 column $(1.6 \times 46 \mathrm{~cm}$, bed volume $92.5 \mathrm{ml}$ ) and eluted with buffer (as above, $5 \mathrm{ml} \mathrm{h}^{-1}$ ). The column was calibrated using the following standards: blue dextran (mol. mass $2 \times 10^{6} \mathrm{Da}$ ); ribonuclease; ovalbumin; albumin; aldolase; catalase; ferritin; thyroglobulin, (Pharmacia gel-filtration calibration kit).

Gel electrophoresis. PAGE with and without SDS was carried out using a Pharmacia Phast system using standard development and staining methods. Molecular mass standards were Pharmacia high or low molecular mass kits. SDS-PAGE for in vitro translation, immunoblotting and immunoprecipitation was done using $16 \times 20 \mathrm{~cm}$
$12.5 \%(w / v)$ polyacrylamide slab gels and Sigma Delta VII-L molecular mass markers. Immunoblotting was done using standard methods as described in Harlow \& Lane (1988).

$R N A$ analysis. Total RNA was prepared by the method of Chambers \& Russo (1986) except that $5 \mathrm{~g}$ of frozen mycelia were used as the starting material. mRNA was purified by two cycles of oligo-dTcellulose chromatography according to Maniatis et al. (1982). Samples were quantified by absorbance at $260 \mathrm{~nm}$. Purified mRNA $(2.5 \mu \mathrm{g})$ was in vitro translated by the method of Pelham \& Jackson (1976) using a rabbit reticulocyte lysate (Amersham) and $\mathrm{L}-\left[{ }^{35} \mathrm{~S}\right]$ methionine (Amersham). Samples $(5 \mu \mathrm{l})$ were removed and solubilized in SDSPAGE sample loading buffer $(30 \mu \mathrm{l})$ [60 mM-Tris $/ \mathrm{HCl}$ pH $6.8,5 \%$ (w/v) SDS, $1 \%(w / v)$ dithiothreitol, $20 \%$ (v/v) glycerol, $0.001 \%$ bromophenol blue]. Samples were heat denatured at $100{ }^{\circ} \mathrm{C}$ before loading onto a $12.5 \%$ SDS-PAGE gel via a $5 \%$ stacking gel. Gels were dried then exposed to X-ray film (Fuji RX) for periods of 12-72 $\mathrm{h}$.

Immunoprecipitation of in vitro translated proteins was done using the method described by Jagus (1987). Anti-cyanide hydratase antiserum was raised in rabbits and supplied by ICI Pharmaceuticals Division, Alderley Park, Cheshire, UK.

cDNA library construction. cDNA was prepared using mRNA isolated from $F$. lateritium culture obtained $57 \mathrm{~min}$ post-cyanide induction using a cDNA synthesis kit (Pharmacia) that uses a method adapted from Gubler \& Hoffman (1983). EcoRI adaptors were ligated to the blunt-ended cDNA for ligation into EcoRI-restricted $\lambda$ gt11 DNA (Young \& Davis, 1983a). Phage were packaged in vitro according to Maniatis et al. (1982). The cDNA library contained $2 \times 10^{5}$ recombinant phage and was amplified in E. coli Y1088 (Young \& Davis, 1983b) using the plate lysate method (Maniatis et al., 1982).

Genomic library construction. Total $F$. lateritium DNA was prepared by the method of Raeder \& Broda (1985) using approximately $0.2 \mathrm{~g}$ of frozen mycelia. Samples of DNA were restricted to completion with $H$ indIII for cloning into the bacteriophage $\lambda$ insertion vector $\lambda$ NM1149 (Murray, 1983). Phage were packaged in vitro as before and recombinants were selected by infection of E. coli NM514 (Murray, 1983). The gene library containing approximately $1 \times 10^{6}$ recombinant phage.

Differential screening. Single-stranded cDNA probes were prepared from mRNA from $F$. lateritium which had been exposed to cyanide for $57 \mathrm{~min}$, and also from $F$. lateritium which had not been exposed to cyanide. These probes were termed induced and uninduced probes 
respectively. Probes were prepared essentially by the method used for the production of $1^{\text {st }}$ strand cDNA described in the Pharmacia kit. Specific activities of cDNA probes were typically $1-2 \times 10^{7}$ c.p.m. per $\mu \mathrm{g}$ of $\mathrm{mRNA}$ reverse transcribed. Probes were denatured before use by heating at $95^{\circ} \mathrm{C}$ for $3 \mathrm{~min}$.

For differential screening, four nitrocellulose filters (Schleicher and Schuell) were prepared from each plate containing recombinant phage (Benton \& Davis, 1977). Filters were prehybridized for at least $1 \mathrm{~h}$ in prehybridization buffer $[6 \times$ SSC, $0.1 \%$ SDS, $0.25 \%$ dried milk powder (Marvel)] at $65^{\circ} \mathrm{C}$. Duplicate filters from each plate were hybridized overnight at $65^{\circ} \mathrm{C}$ with induced and uninduced cDNA probes in hybridization buffer $(3 \times \mathrm{SSC}, 0.1 \%$ SDS, $0.02 \%$ Ficoll, $0.02 \%$ polyvinylpyrrolidone). Filters were washed in three changes of wash buffer $(2 \times \mathrm{SSC}, 0 \cdot 1 \% \mathrm{SDS})$, preheated at $65^{\circ} \mathrm{C}$. Exposure of filters to $\mathrm{X}$-ray film was from overnight to $72 \mathrm{~h}$ with two Cronex Lightening Plus intensifying screens.

Oligonucleotide probing. The oligonucleotide solution used was a mixture of 256 different oligonucleotides (20-mers) synthesized to ensure all possible sequences of the heptapeptide Ala Phe Pro Glu Val Trp Ile (the last base of Ile was omitted). This sequence was determined from random sequencing of a partial hydrolysis of pure cyanide hydratase. The oligonucleotide mixture was supplied by ICI Pharmaceuticals Division at a concentration of $67.2 \mu \mathrm{g} \mathrm{m}^{-1}$ as judged by absorbance at $260 \mathrm{~nm}$. The oligonucleotides were end-labelled with $\left.{ }^{32} \mathrm{P}\right] \mathrm{dATP}$ (Amersham) using T4 polynucleotide kinase according to Maniatis et al. (1982) and gave specific activities of $2 \times 10^{8}$ c.p.m. per $\mu \mathrm{g}$ DNA.

Filters were pre-hybridized at $65^{\circ} \mathrm{C}$ for $3 \mathrm{~h}$ in $6 \times \mathrm{NET}(90 \mathrm{mM}$ Tris/HCl, pH 8.3, 0.9 M-NaCl, 6 mm-EDTA), $0.1 \%$ SDS, $5 \times$ Denhardt's solution, $100 \mathrm{mg}$ calf thymus DNA ml${ }^{-1}$. This solution was replaced with $6 \times \mathrm{NET}, 0 \cdot 1 \% \mathrm{SDS}, 5 \times$ Denhardt's solution and $6 \mathrm{ng}$ end-labelled oligonucleotide $\mathrm{ml}^{-1}$. A $1 \mathrm{ml}$ vol. of hybridization solution was used per filter and hybridization was at $44^{\circ} \mathrm{C}$ for $2 \mathrm{~h}$. The hybridization temperature was calculated from Wallace \& Miyada (1987). Filters were washed in $6 \times \mathrm{SSC}, 0.1 \%$ SDS at $4{ }^{\circ} \mathrm{C}$ with four changes of buffer for $5 \mathrm{~min}$ each then for $5 \mathrm{~min}$ at the hybridization temperature. Filters were exposed to X-ray film overnight.

Expression studies. The expression vector pGEX-2T was used for expression in E. coli (Smith \& Johnson, 1988). In pGEX-2T, sequences to be expressed are fused to the glutathione $S$-transferase gene linked to the strong tac promoter. Crude extracts for protein analysis were prepared by growing cultures to mid-exponential phase before adding IPTG to $1 \mathrm{~mm}$. The cultures were then grown for a further $2 \mathrm{~h}$ at $37^{\circ} \mathrm{C}$. A $1.5 \mathrm{ml}$ vol. of culture was pelleted by centrifugation in a microfuge for $3 \mathrm{~min}$; the pellet was then resuspended in $50 \mu 1$ SDS-PAGE sample buffer and boiled for $2 \mathrm{~min}$. Samples $(15 \mu \mathrm{l})$ were run on SDS-PAGE gels.

DNA manipulations. Standard methods were used for Southern blotting, nick-translation, phage and plasmid DNA isolations, gel electrophoresis, subcloning and restriction analysis (Maniatis et al., 1982). DNA sequencing was by the dideoxy chain termination method of Sanger et al. (1977) adapted for double-stranded DNA by Chen \& Seeburg (1985). Non-standard sequencing primers were synthesized on an Applied Biosystems 381A DNA synthesiser at the Department of Biological Sciences, University of Durham, UK.

\section{Results and Discussion}

\section{Induction of cyanide hydratase activity}

Cyanide hydratase activity was induced by addition of sodium or potassium cyanide to continuously grown culture (Richardson \& Clarke, 1987). In a typical fermentation, $F$. lateritium was grown at a dilution rate of $0.08 \mathrm{~h}^{-1}$ and a cell dry wt of $12.0 \mathrm{~g} \mathrm{l}^{-1}$. No activity was detected in cells before exposure to cyanide, [i.e. $<0.02 \mathrm{U}\left(\mathrm{mg} \mathrm{dry} \mathrm{wt}^{-1}\right.$ ]. Sodium cyanide $(5 \mathrm{M})$ was added to the culture at $0.85 \mathrm{mM} \mathrm{h}^{-1}$ for $50 \mathrm{~min}$. It should be noted that the considerable 'dead volume' of the addition system resulted in the first indication of cyanide in the fermenter at $37 \mathrm{~min}$ (detection of hydrogen cyanide by exhaust gas analyser). Cyanide addition was ceased in response to this observation. The RNA preparations from which cyanide hydratase mRNA was isolated (see below) were made from mycelium taken at $57 \mathrm{~min}$. Cyanide hydratase activity was detected after $71 \mathrm{~min}$. After the initial detection of activity, the cyanide addition rate was increased in steps. The maximum steady state activity obtained was $102.5 \mathrm{U}(\mathrm{mg} \text { dry } \mathrm{wt})^{-1}$ obtained over a $36 \mathrm{~h}$ period during which $6.0-6.4 \mathrm{~mm} \mathrm{~h}^{-1}$ of cyanide was added.

\section{Enzyme purification}

The results of a typical purification are shown in Table 2 . The culture used in this experiment was obtained by induction under conditions similar to those described above but on a smaller scale. The starting material was 15.81 containing $74.9 \mathrm{~g}$ dry wt of mycelium having an activity of $19.6 \mathrm{U}(\mathrm{mg} \text { dry } \mathrm{wt})^{-1}$. The purified enzyme eluted from the gel-filtration column as a single peak and formed one major band on SDS-PAGE. The purification factor of $19 \cdot 8$ (Table 2) indicates that the enzyme formed $5 \%$ of the soluble protein in these cells. This suggests that in the maximally induced cells described above [activity $102.5 \mathrm{U}(\mathrm{mg} \text { dry } \mathrm{wt})^{-1}$ ] around $25 \%$ of the soluble protein was cyanide hydratase (the soluble protein was $22 \%$ of the total dry wt).

\section{Enzyme properties}

The $K_{\mathrm{m}}$ for cyanide was found to be $43 \mathrm{~mm}$. Rapid inactivation by cyanide was observed at concentrations over $150 \mathrm{~mm}$. Formamide was found not to be a substrate and did not inhibit the hydration of cyanide. The $\mathrm{pH}$ profile showed an optimum at $\mathrm{pH} 8.5$, the decline at high

Table 2. Purification of cyanide hydratase from $F$. lateritium

\begin{tabular}{lcc}
\hline \multicolumn{1}{c}{ Fraction } & $\begin{array}{c}\text { Specific activity } \\
\left(\mathrm{U} \mathrm{mg}^{-1}\right)\end{array}$ & $\begin{array}{c}\text { Purification } \\
\text { factor }\end{array}$ \\
\hline Crude lysate & $55 \cdot 9$ & 1 \\
17000 g supernatant & $87 \cdot 8$ & 1.5 \\
DEAE-bound fraction & 354 & $6 \cdot 3$ \\
$\left(\mathrm{NH}_{4}\right)_{2} \mathrm{SO}_{4}$ pellet & 667 & 11.9 \\
Ion-exchange peak & 1102 & $19 \cdot 7$ \\
Gel-filtration peak & 1109 & $19 \cdot 8$ \\
\hline \hline
\end{tabular}




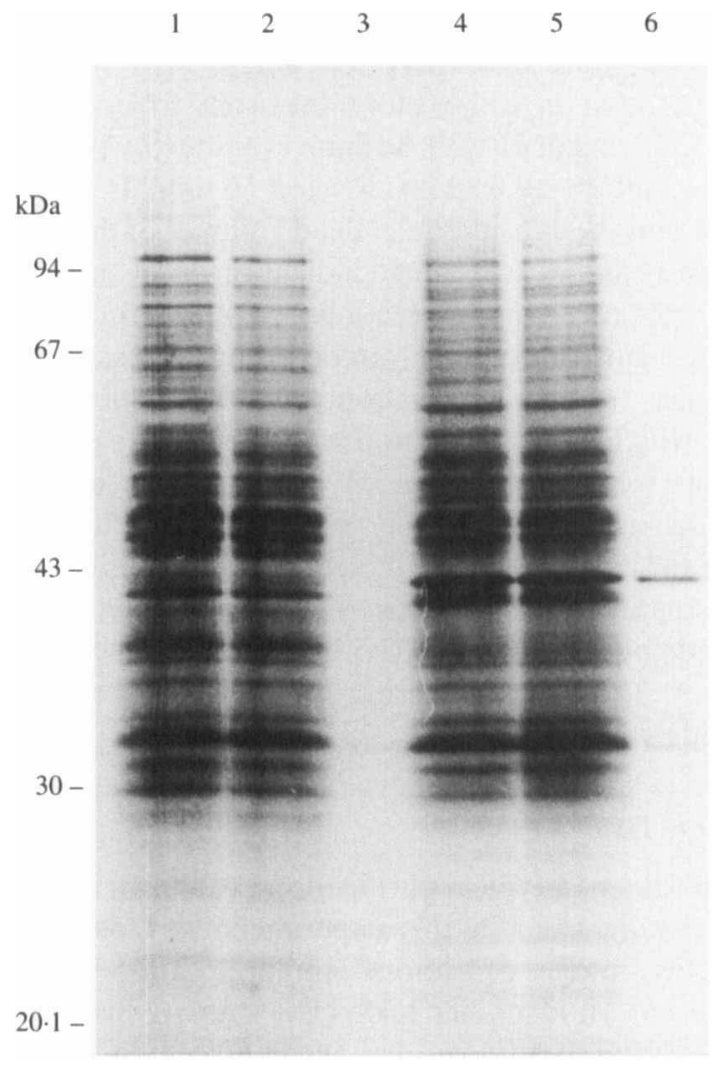

Fig. 1. In vitro translation and immunoprecipitation. Lanes 1 and 2 show duplicate in vitro translations of $\mathrm{mRNA}$ isolated from uninduced F. lateritium culture. Lane 3 shows immunoprecipitation of products from uninduced in vitro translations with anti-cyanide hydratase antiserum (see text for details). Lanes 4, 5 and 6 are as for lanes 1,2 and 3 except that mRNA isolated from cyanide-induced cultures was used for in vitro translation.

$\mathrm{pH}$ following the titration curve for cyanide, $(\mathrm{p} K$ 9.2). These properties are similar to those described previously for the enzyme from $S$. loti and G. sorghi (Fry \& Millar, 1972; Fry \& Munch, 1975; Fry \& Myers, 1982) and from F. solani (Shimizu \& Taguchi, 1969). The purified enzyme described above exhibited a subunit molecular mass of $43 \mathrm{kDa}$ on SDS-PAGE electrophoresis. This is in reasonable agreement with the estimate of $40 \mathrm{kDa}$ reported for $F$. solani, although a second strain was reported to contain an enzyme with a subunit molecular mass of only $17 \mathrm{kDa}$ (Shimizu \& Taguchi, 1969).

The gel-filtration elution profile obtained for purified enzyme indicated the native molecular mass to be very high. Non-denaturing PAGE revealed several proteins of molecular mass $300-400 \mathrm{kDa}$, despite the apparent purity on denaturing gels. This was explored further using a calibrated gel-filtration column and gel electrophoresis. In order to extract material as rapidly as possible, dried mycelium was obtained from the CYCLEAR production plant and ground using a domestic coffee grinder. The powder was extracted using $100 \mathrm{~mm}-\mathrm{Tris} / \mathrm{HCl}(\mathrm{pH} \mathrm{8.5)}$ buffer in a Potter-Elvehjem homogenizer. The supernatant obtained by centrifugation $(17000 \mathrm{~g}, 15 \mathrm{~min})$ contained $25.8 \mathrm{U}(\mathrm{mg}$ dry mycelium $)^{-1}$ and was analysed by gel-filtration as described above. The peak fraction was eluted at a volume corresponding to a molecular mass of $313 \mathrm{kDa}$ but the activity was distributed over a range of $272-1217 \mathrm{kDa}$. The crude supernatant and the gel-filtration peak were examined by PAGE in the presence and absence of SDS. The SDS gel (not shown) indicated the subunit molecular mass to be as described above, both in the crude extract and in the column eluate. The native enzyme after gelfiltration behaves as predicted by the gel-filtration elution profile (not shown). The crude supernatant, however, shows much higher molecular masses, a significant proportion of the protein failing to enter the resolving gel (not shown). Dissection of the gels and prolonged incubation in the standard assay system indicated the regularly spaced bands at the top of the gel to be active cyanide hydratase; however, the assay was not sensitive enough to be more than a qualitative test. No activity was detected in the rest of the gel.

The native molecular mass of the enzyme from $S$. loti was not determined, although it was observed to elute in the void volume of a Sephadex G-200 column (exclusion limit $600 \mathrm{kDa}$ ) (Fry \& Millar, 1972). The G. sorghi enzyme was later reported to be between 2000 and $10000 \mathrm{kDa}$ (Fry \& Munch, 1975). The results reported here indicate that for $F$. lateritium the enzyme is also aggregated into what must approach a particulate structure in vivo. It exhibits, however, a tendency to dissociate not shown previously. The failure of protein dissociated during gel-filtration to reassociate when analysed by PAGE indicates the process to be irreversible. The observations that the aggregates are active and do not reassociate suggest that they do reflect a genuine in vivo behaviour. This behaviour is similar to that reported for several other enzymes in related areas of metabolism. The $\beta$-glycosidase of Hevea brasiliensis breaks down the cyanogenic glycoside linamarin, and exhibits a reversible dissociation into aggregates of up to $1700 \mathrm{kDa}$ (Selmar et al., 1987). The nitrilase from $F$. oxysporum was reported to form active oligomers of between 4 and 14 subunits, with molecular masses up to

Fig. 2 (facing page). Nucleotide sequence of the cyanide hydratase gene and predicted protein sequence of the cyanide hydratase enzyme. Putative $5^{\prime}$ and $3^{\prime}$ control sequences are shown in capitals as is the coding region. The boxed regions spanning the second intron indicate the peptide sequence used in the production of the oligonucleotide. 
-160 tgtatcagtttgacagtcagtgtgttatacCAAATtcttgtctgtgtatctggTATAAAtatctagctctgcegcatcca -81

-80 aatcatcaatatcacattcatcatcacacagaaacactacaatcaaacaatcccaacagttctctttatcaaccttcatc -1

1 ATG GCT ATC ACC AAG TAC AAG GCC GCC GCT GTC ACC TCC GAG CCT GGA gtgagtctctcaccac 64

$\begin{array}{llllllllllllllllll}1 & M & A & I & T & K & Y & K & A & A & A & V & T & S & E & P & G & \\ \end{array}$

65 tacaacaccgatgcatttactgacgatatttag TGG TTC GAC CTC GAG GGC GGC GTT CGC AAG ACC 130 17

131 ATT GAC TTC ATC AAC GAG GCT GGT GAA GCT GGA TGC AAG TTC GTT GCC TTT CCC GAA GIgt 190 $\begin{array}{lllllllllllllllllllll}28 & I & D & F & I & N & E & A & G & E & A & G & C & K & F & V & A & F & P & E & V\end{array}$

191 aagttttttcacattttaatgaatttacaatatctaatacccaacag TT TGG ATP CCT GGA TAT CCC TAC 261 48 $\begin{array}{lllllll}W & P & G & Y & P & Y & 54\end{array}$

262 TGG ATG TGG AAG GT ACC TAC CTC CAG TCT CTC CCT ATG CTC AAG AGG TAC CGT GAG AAC 321 $\begin{array}{llllllllllllllllllllll}55 & \mathrm{~W} & M & \mathrm{~W} & \mathrm{~K} & \mathrm{~V} & \mathrm{~T} & \mathrm{Y} & \mathrm{L} & \mathrm{Q} & \mathrm{S} & \mathrm{L} & \mathrm{P} & \mathrm{M} & \mathrm{L} & \mathrm{K} & \mathrm{R} & \mathrm{Y} & \mathrm{R} & \mathrm{E} & \mathrm{N} & 74\end{array}$

322 TCC ATG GCT GTC GAC TCT GAG GAG ATG CGC CGC ATC CGA CGC GCT GCT CGC GAT AAC CAG 381 $\begin{array}{llllllllllllllllllllll}75 & S & M & A & V & D & S & E & E & M & R & R & I & R & R & A & A & R & D & N & Q & 94\end{array}$

382 ATC TTT GTC TCT CTS GGA TTC TCC GAG ATT GAC CAC GCC ACT CTT TAC CTT TCC CAG GTT 441

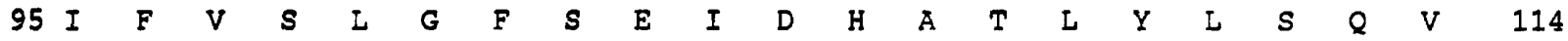

442 CTG ATC GGT CCT GAT GGT GCC GTC ATC AAC CAC CGC CGC AAG ATC AAG CCC ACT CAT GTT 501 $\begin{array}{llllllllllllllllllllll}115 & \mathrm{~L} & \mathrm{I} & G & \mathrm{P} & \mathrm{D} & G & \mathrm{~A} & \mathrm{~V} & \mathrm{I} & \mathrm{N} & \mathrm{H} & \mathrm{R} & \mathrm{R} & \mathrm{K} & \mathrm{I} & \mathrm{K} & \mathrm{P} & \mathrm{T} & \mathrm{H} & \mathrm{V} & 134\end{array}$

502 GAG AAG CTC GTT TAC GGT GAT GGA TCC GGT GAC ACC TTC ATG TCT GTC AGT GAG ACT GAG 561 $\begin{array}{llllllllllllllllllllll}135 & E & \mathbb{X} & \text { L } & V & Y & G & D & G & S & G & D & T & F & M & S & V & S & E & T & E & 154\end{array}$

562 ATT GGC CGC GTC GGT CAG CTC AAC TGC TGG GAG AAC ATG AAC CCC TTC CTC AAG TCT CTC 621

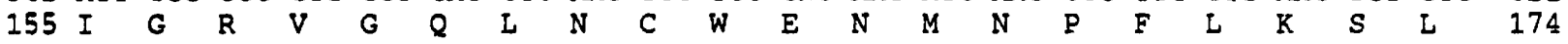

622 AAC GTC TCT GCT GGT GAG CAG GTT CAC GTT GCT GCA TGG CCT GTC TAC CCT GGC AAG GAG 681

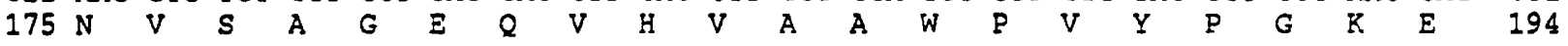

682 CGC CAG GTT CAC CCC GAC CCT GCT ACC AAC TAT GCC GAT CCA GCC TCT GAC CTG GTT ACT 741

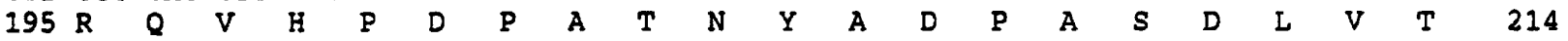

742 CCT GAG TAT GCT ATC GAG ACT GGC ACG TGG ACT CTT GCT CCC TTC CAG CGT CTC TCG GTT 801 $\begin{array}{llllllllllllllllllllll}215 & P & E & Y & A & I & E & T & G & T & W & T & L & A & P & F & Q & R & \text { L } & S & V & 234\end{array}$

802 GAG GGT CTG AAG ATC AAC ACT CCT GAG GGT GTT GAG CCC GAG ACC GAC CCC TCG GTT TAC 861

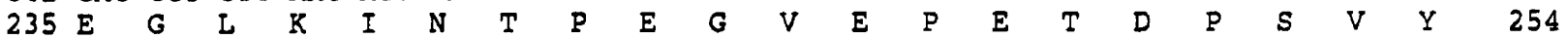

862 AAC GGT CAT GCC CGI ATC TAC CGA CCC GAC GGT AGC CTT GTT GTC AAG CCT GAG AAA GAC 921

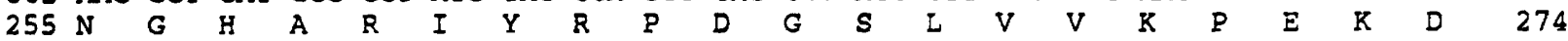

922 TTC GAT GGT CTT CTA TTT GTT GAC ATC GAT CTA AAC GAG TGC CAT CTG ACC AAG GTC CTC 981 $\begin{array}{llllllllllllllllllllll}275 & F & D & G & L & L & F & V & D & I & D & L & N & E & C & H & \text { L } & T & K & V & L & 294\end{array}$

982 GCT GAC TTT GCT GGC CAC TAC ATG CGC CCT GAT CTC ATT CGC CTT CTG GTC GAC ACT CGC 1041 $\begin{array}{llllllllllllllllllllll}295 & \text { A } & D & \text { D } & \text { A } & G & H & \text { Y } & \text { M } & \text { R } & \text { P } & \text { D } & \text { L } & \text { I } & \text { R } & \text { L } & \text { L } & \text { V } & \text { D } & \text { T } & \text { R } & 314\end{array}$

1042 CGC AAG AAA CTC ATC ACT GAG GCT GAC CCT AAC GGC TCC ATT GCT ACC TAC AGT ACT CGC 1101

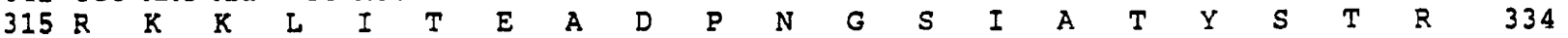

1102 CAG AGA CTT GGA TTG GAC AAG CCT CTT TCG AAG AAG GAG GGA GAT GAG ACA ACT GAC GTG 1161

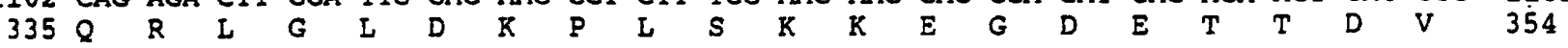

1162 CTC TGA atgagacttgacgaggttggggttatcaccgccaaggatgatttcatctgatgatggatggaacttgtaaga 1239 $355 \mathrm{~L}$ 
$550 \mathrm{kDa}$ (Goldlust \& Bohak, 1989). In this case, the dissociation was apparently irreversible as for cyanide hydratase, although the initial state was not so highly aggregated.

\section{Molecular cloning of cyanide-inducible genes}

Cyanide hydratase activity is detectable only in cultures of $F$. lateritium which have been exposed to cyanide. This suggests that expression of the gene encoding cyanide hydratase may be inducible. Differential screening of a $F$. lateritium cDNA library was the method chosen to obtain a cyanide hydratase cDNA clone, utilizing cDNA probes prepared from mRNA isolated from cyanideinduced and uninduced cultures. The validity of this approach was tested by in vitro translation of $\mathrm{mRNA}$ from uninduced and induced culture followed by the immunoprecipitation of the translation products with an antibody specific for cyanide hydratase. Fig. 1 illustrates immunoprecipitations of in vitro translation products of uninduced mRNA and induced mRNA from the $57 \mathrm{~min}$ post-cyanide-induction time point. Close examination of the autoradiograph indicates that a number of proteins are apparently induced by cyanide, but the most obvious of these is a protein of approximate molecular mass $43 \mathrm{kDa}$, which is precipitated by the cyanide-hydratasespecific antiserum. These results confirm that expression of the $F$. lateritium cyanide hydratase gene is inducible by cyanide, and so justifies the differential screening approach taken to isolate a cyanide hydratase cDNA clone.

\section{Differential screening}

A cDNA library containing $2 \times 10^{5}$ recombinants was generated in $\lambda$ gt11 using mRNA isolated 57 min postcyanide induction. A sample of the cDNA library corresponding to 10000 recombinant phage was differentially screened as described. Five differentially hybridizing clones were obtained that were found to give a reproducible hybridization pattern following subsequent rounds of screening. Initially, two clones were used for further study; purification and analysis of the remaining clones is currently under way. The EcoRI inserts from the two $\lambda$ gt11 phage were subcloned into $\mathrm{pUC} 18$ to give pMC111 and pMC211. EcoRI digestion of pMC111 and pMC211 showed cDNA insert sizes of $0.68 \mathrm{~kb}$ and $1.2 \mathrm{~kb}$ respectively.

\section{Identification of the cyanide hydratase gene (chyl)}

A Southern blot of EcoRI digests of pMC111 and pMC211 was probed with the degenerate end-labelled oligonucleotide derived from a partial sequence of the cyanide hydratase protein. The oligonucleotide was found to hybridize strongly to the pMC211 cDNA insert (data not shown). Subsequent repeat experiments in which the blot was washed $4 \times 15 \mathrm{~min}$ at room temperature followed by a $1 \times 15 \mathrm{~min}$ wash at $52^{\circ} \mathrm{C}\left(8^{\circ} \mathrm{C}\right.$ above the calculated $T_{\mathrm{d}}-2^{\circ} \mathrm{C}$ temperature) gave autoradiographs which showed no difference in the intensity of the signal obtained with the pMC211 cDNA insert. The fact that pMC211, already shown to represent a cyanide-inducible cDNA by virtue of its differential hybridization pattern, also hybridized to an oligonucleotide probe derived from the cyanide hydratase protein sequence, led to the conclusion that pMC211 was in a cyanide hydratase cDNA clone.

\section{Isolation of a cyanide hydratase genomic clone}

A total of 25000 clones from the $F$. lateritium genomic library was screened using the purified cDNA insert from pMC211. Eight strongly hybridizing clones were obtained and DNA was isolated from each of these clones. Each clone was shown to contain the same $9.0 \mathrm{~kb}$ HindIII fragment. The $9.0 \mathrm{~kb}$ HindIII fragment was subcloned into pUC9 to give $\mathrm{pCH} 1$.

\section{Sequence analysis of the cyanide hydratase gene}

The cDNA clone pMC211 was sequenced, revealing an open reading frame (ORF) of $1014 \mathrm{bp}$ encoding a peptide of molecular mass $35 \mathrm{kDa}$ with no obvious methionine translation initiation codon. Therefore, the cDNA library was rescreened to isolate a full length clone. This clone, pMC 311 , contains an extra $84 \mathrm{bp}$ at the $5^{\prime}$ end of the gene but is a little shorter at the $3^{\prime}$ end. The ATG codon at position +1 (Fig. 2) is taken as the translation start point as it marks the beginning of a $1068 \mathrm{bp} \mathrm{ORF}$ encoding a protein 355 amino acids long with a predicted molecular mass of $39.9 \mathrm{kDa}$. The predicted size of the cyanide hydratase protein is in good agreement with the size of $43 \mathrm{kDa}$ estimated by biochemical determinations of the purified enzyme.

The sequence of a region of approximately $1.5 \mathrm{~kb}$ of the genomic clone, corresponding to the coding region plus $198 \mathrm{bp}$ of $5^{\prime}$ untranslated sequence, has been determined (Fig. 2) to confirm the delimitation of the coding region. This sequence shows that there is an inframe stop codon at position -105 and from that point downstream to the presumptive translation start codon, there are no further in-frame ATG codons. The sequence of the genomic clone reveals the presence of two introns in the $c y h 1$ gene, both near the 5- end of the gene. The boundary sequences and the internal sequences of both introns are in good agreement with the consensus sequences proposed for fungal introns (Gurr et al., 1987). A putative promoter region has been identified and the 
(a)

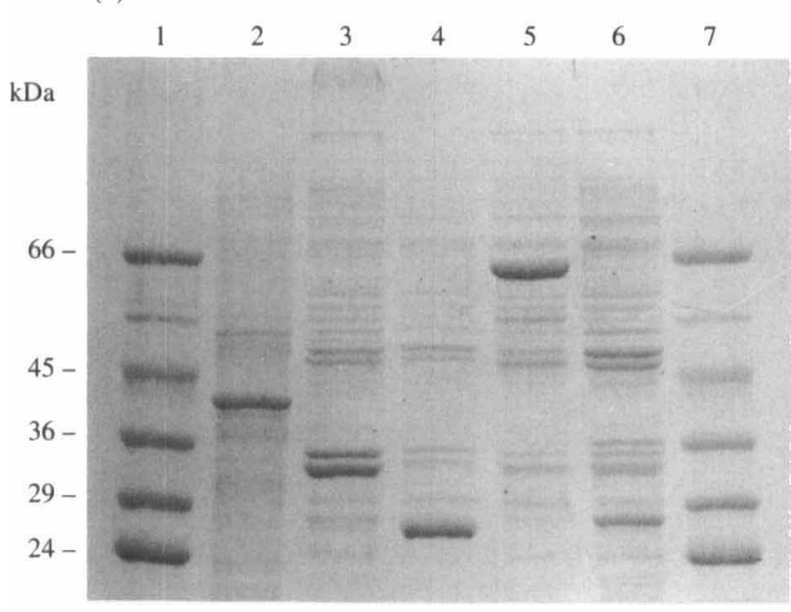

(b)

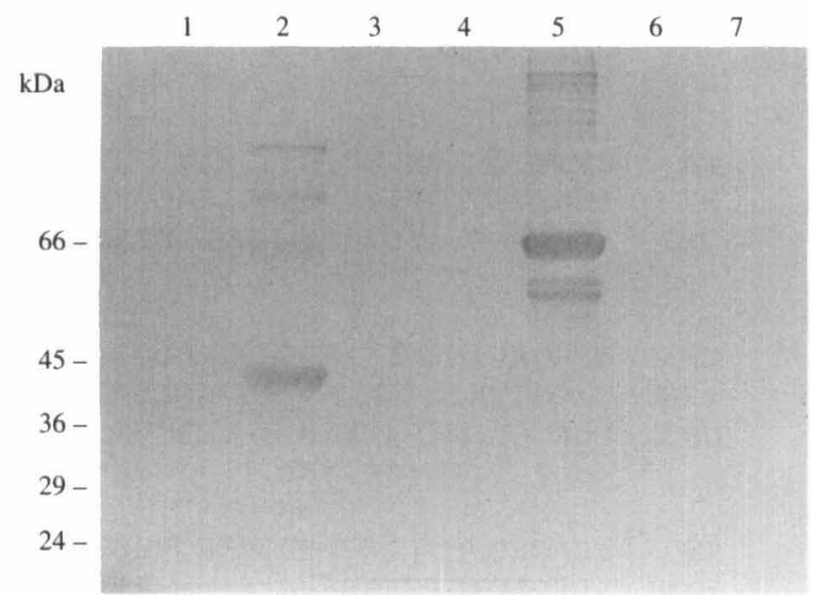

Fig. 3. SDS-PAGE of ( $a$ ) crude cell extracts (Coomassie-blue-stained) and (b) the corresponding Western blot showing expression of cyanide hydratase as a glutathione $S$-transferase fusion protein in $E$. coli. Lanes are as follows: 1, molecular mass markers; 2 , cyanideinduced F. lateritium; 3, E. coli XL1-Blue; 4, pGEX2T; 5, pGEX312 (correct orientation); 6, pGEX313 (reverse orientation); 7, molecular mass markers.

CAAT and TATA sequences are indicated in Fig. 2. A sequence, CAACCTT, bearing strong homology to the proposed ribosome binding site (CCACCTT) of the Neurospora crassa am gene (Kinnaird \& Fincham, 1983) is found at -5 in $c y h 1$.

The sequence of the $3^{\prime}$ region of pMC211 shows that no polyadenylated tail is present in this clone, although the mRNA used to construct the library was purified by two cycles of oligo-dT-cellulose chromatography and cDNA synthesis was primed using oligo-dT. It can only be concluded that the polyA tail was lost during the cloning process. The sequence of the $3^{\prime}$ untranslated region of $c y h 1$ contains two putative polyadenylation signal sequences (Proudfoot \& Brownlee, 1976), both of which have the sequence AAATA.

Recently, cyanide hydratase has been purified and the gene cloned from the phytopathogenic fungus Gloeocercospora sorghi (Wang et al., 1992; Wang \& Van Etten, 1992). The enzyme is very similar in properties to the enzyme from $F$. lateritium. The genes are approximately $65 \%$ homologous and the proteins are $75 \%$ identical. Interestingly, the $G$. sorghi gene does not have any introns.

\section{Expression of cyanide hydratase in $E$. coli}

A cyanide hydratase cDNA clone, pMC312, was identified which contains an ORF for all but the first seven amino acids of cyanide hydratase. In order to confirm the identity of the protein encoded by the cloned cyh 1 gene, the $1090 \mathrm{bp}$ fragment of pMC312 was fused in-frame with the glutathione $S$-transferase (GST) gene in the expression vector pGEX-2T (Smith \& Johnson, 1988) to give pGEX-312. Insertion of the fragment in the reverse orientation gave pGEX-313. Analysis of crude cell extracts of E. coli containing these plasmids (Fig. 3) indicates that pGEX-312 leads to the production of a novel protein of approximately $66 \mathrm{kDa}$ while pGEX-313 leads to the production of a protein of approximately $28 \mathrm{kDa}$ (the GST protein itself is $26 \mathrm{kDa}$ ). The $66 \mathrm{kDa}$ protein produced by pGEX-312 is the expected size for the GST-CYH fusion protein. Immunoblotting of this gel with the cyanide hydratase antiserum confirms that this protein reacts strongly with the antiserum while no reaction is found in the control extracts. No detectable cyanide hydratase enzyme activity was observed in extracts of $E$. coli strains expressing the GST-CYH fusion protein.

\section{Homology of cyanide hydratase to other proteins}

The predicted protein sequence of cyanide hydratase was compared to the NBRF Data Bank using Microgenie software. This revealed that the cyanide hydratase protein has remarkable homology to the bromoxynilspecific nitrilase from Klebsiella pneumoniae (Stalker et al., 1988), showing $35 \%$ identity over the entire length of the proteins (Fig. 4). Recently, the sequence of a nitrilase from Alcaligenes faecalis JM3 has been published (Kobayashi et al., 1993) and this is approximately $35 \%$ homologous to both cyanide hydratase and the Klebsiella nitrilase. The alignment of the three sequences is shown in Fig. 4. Interestingly, the cysteine residue at position 163 in the Alcaligenes nitrilase, which has been shown to be required for activity (Kobayashi et al., 1993), is conserved in both cyanide hydratase and the bromoxynil nitrilase. Site-directed mutagenesis will be used to establish the importance of this residue in cyanide 


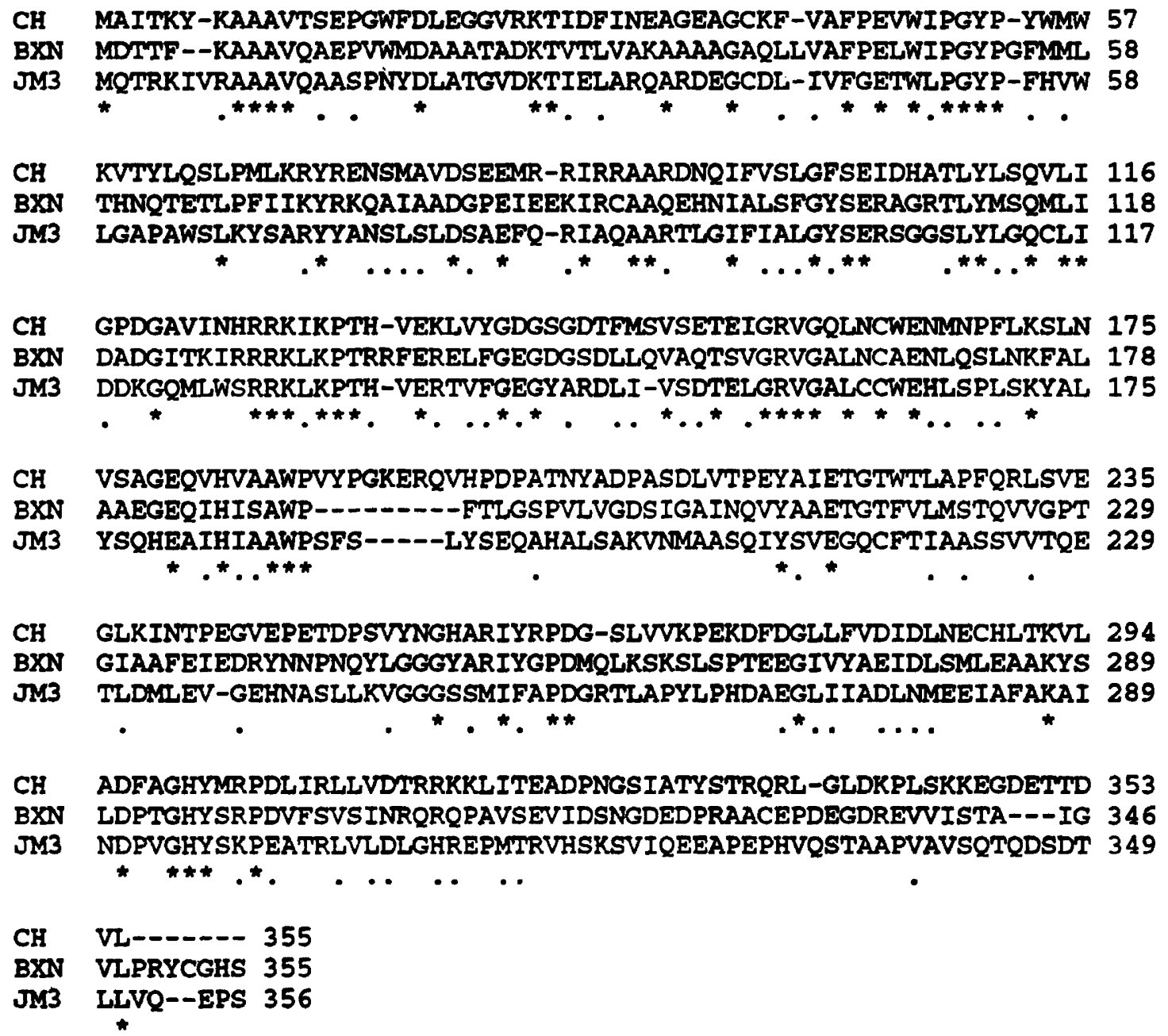

Fig. 4. Comparison of amino acid sequence of $F$. lateritium cyanide hydratase $(\mathrm{CH})$ with the $K$. pneumoniae bromoxynil-specific nitrilase (BXN) and the nitrilase from Alcaligenes faecalis JM3 (JM3). The sequences were aligned using the Clustal program available through the SERC Daresbury Laboratory computer system. Identical amino acids are indicated by (*), similar changes are marked by (.).

hydratase. The similarity of cyanide hydratase to nitrilases is a little surprising, as one may anticipate a greater degree of similarity to the functionally similar nitrile hydratases. This may be explained by the reaction scheme previously proposed (Zervos \& Cordes, 1971), in which nitriles mav be converted via a thioimidate intermediate to either amide or acid depending on conditions. However, no homology was seen to the nitrile hydratases from Rhodococcus sp. 774 (Kobayashi et al., 1991) and Myrothecium verrucaria (Endo \& Watanabe, 1989; Maier-Greiner et al., 1991). There are no reports in the literature of cyanide being used by either nitrilases or nitrile hydratases. The similarity of cyanide hydratase to the bromoxynil nitrilase does not appear to reflect the structural similarities seen between cyanide hydratase and the $F$. oxysporum nitrilase (see above), as the $K$. pneumoniae enzyme does not form aggregates. No nitrilase activity was found in crude extracts of $F$. lateritium prepared from cultures with a high level of cyanide hydratase activity (P. D. Turner, unpublished).

The authors wish to acknowledge the help of Dr J. Fitton of ICI Pharmaceuticals Division. Thanks are also due to Dr A. Tommey for advice on $E$. coli expression studies and $\mathrm{Mr} \mathrm{D}$. Hutchinson, $\mathrm{Mr} \mathrm{J}$. Hutchinson and Mr P. Griffin for photographic assistance.

\section{References}

BENTON, W. D. \& DAVIS, R. W. (1977). Screening of $\lambda$ gt recombinant clones by hybridization to single plaques in situ. Science 196, 180-182.

Bullock, W. O., Fernandez, J. M. \& Short, J. M. (1987). XL1-Blue: a high efficiency plasmid transforming recA Escherichia coli strain with $\beta$-galactosidase selection. Biotechniques 5, 376-378.

Chambers, J. A. A. \& Russo, V. E. A. (1986). Isolating RNA is easy and fun. Fungal Genetics Newsletter 33, 22-24. 
Chen, E. Y. \& SeEburg, P. H. (1985). Supercoil sequencing: a fast and simple method for sequencing plasmid DNA. DNA 4, 165-170.

ENDO, T. \& WATANABE, I. (1989). Nitrile hydratase of Rhodococcus sp. N774-purification and amino acid sequences. FEBS Letters 243 , 61-64.

FRY, W. E. \& EvaNs, P. H. (1977). Association of formamide hydrolase with fungal pathogenicity to cyanogenic plants. Phytopathology 61, 494-500.

FRY, W. E. \& Millar, R. L. (1972). Cyanide degradation by an enzyme from Stemphylium loti. Archives of Biochemistry and Biophysics 151, $468-474$.

FRY, W. E. \& MuNCH, D. C. (1975). Hydrogen cyanide detoxification by Gloeocercospora sorghi Physiological Plant Pathology 7, 23-33.

FrY, W. E. \& MYERS, D. F. (1982). Hydrogen cyanide metabolism by fungal pathogens of cyanogenic plants. In Cyanide in Biology, pp. 321-334. Edited by B. Vennesland, E. E. Conn, C. J. Knowles, J. Westley \& F. Vissing. London: Academic Press.

Goldlust, A. \& BoHAK, Z. (1989). Induction, purification, and characterization of the nitrilase of Fusarium oxysporum $F$. sp. melonis. Biotechnology and Applied Biochemistry 11, 581-601.

GubleR, U. \& HofFMAN, B. J. (1983). A simple and very efficient method for generating cDNA libraries. Gene 25, 263-269.

GuRR, S. J., UnkLes, S. E. \& KINGHORN, J. R. (1987). The structure and organization of nuclear genes of filamentous fungi. In Gene Structure in Eukaryotic Microbes, pp. 93-139. Edited by J. R. Kinghorn. Oxford: IRL Press.

HaRlow, E. \& LANE, D. (1988). Antibodies. A Laboratory Manual. Cold Spring Harbor, NY: Cold Spring Harbor Laboratory.

HARRIS, R. E. \& KNOWLES, C. J. (1983). Isolation and growth of a Pseudomonas species that utilizes cyanide as a source of nitrogen. Journal of General Microbiology 129, 1005-1011.

JAGUS, R. (1987). Characterisation of in vitro translation products. Methods in Enzymology 152, 296-304.

KinNaird, J. H. \& Fincham, J. R. S. (1983). The complete nucleotide sequence of the Neurospora crassa am (NADP-specific glutamate dehydrogenase) gene. Gene 26, 253-260.

KNOWLES, C. J. (1976). Microorganisms and cyanide. Bacteriological Reviews 40, 652-680.

Knowles, C. J. (1988). Cyanide compounds in biology. Ciba Foundation Symposium. 140, 3-15. Chichester: John Wiley.

Kobayashi, M., Nishiyama, M., Nagasawa, T., Horinouchi, S., BePPU, T. \& YAMADE, H. (1991). Cloning, nucleotide sequence and expression in Escherichia coli of two cobalt-containing nitrile hydratase genes from Rhodococcus rhodochrous J1. Biochimica et Biophysica Acta 1129, 23-33.

Kobayash, M., IzUi, H., Nagasawa, T. \& Yamada, H. (1993). Nitrilase in biosynthesis of the plant hormone indole-3-acetic acid from indole-3-acetonitrile: cloning of the Alcaligenes gene and sitedirected mutagenesis of cysteine residues. Proceedings of the National Academy of Sciences of the United States of America 90, 247-251.

Maier-Greiner, U. H., OBERMaIER-SKrobraneK, B. M. M., Estermaier, L. M., Kammerloher, W., Freund, C., Wulfing, C., Burkert, U. I., Matern, D. H., BreuER, M., EulitZ, M., Kufrevioglu, O. I. \& HaRtmanN, G. R. (1991). Isolation and properties of a nitrile hydratase from the soil fungus Myrothecium verrucaria that is highly specific for the fertiliser cyanamide and cloning of its gene. Proceedings of the National Academy of Sciences of the United States of America 88, 4260-4264.

Maniatis, T., Fritsch, E. F. \& Sambrook, J. (1982). Molecular Cloning. A Laboratory Manual. Cold Spring Harbor, NY: Cold Spring Harbor Laboratory.
Murray, N. E. (1983). Phage $\lambda$ and molecular cloning. in Lambda II, pp. 395-432. Edited by R. W. Hendrix, J. W. Roberts, F. W. Stahl \& R. A. Weisburg. Cold Spring Harbor, NY: Cold Spring Harbor Laboratory.

Pelham, H. R. B. \& JACKSON, R. J. (1976). An efficient mRNAdependent translation system from reticulocyte lysates. European Journal of Biochemistry 67, 247-256.

Proudfoot, N. J. \& BrownLEe, G. G. (1976). 3' non-coding region sequences in eukaryotic messenger RNA. Nature, London 263, 211-214.

RAEDER, U. \& BRODA, P. (1985). Rapid preparation of DNA from filamentous fungi. Letters in Applied Microbiology 1, 17-20.

RAMBoSEK, J. \& LEACH, J. (1987). Recombinant DNA in filamentous fungi: progress and prospects. CRC Critical Reviews in Biotechnology 6, 357-393.

Richardson, K. R. \& Clarke, P. M. (1987). European Patent no. 234760. Production of cyanide hydratase.

SANGer, F., Nicklen, S. \& Coulson, A. R. (1977). DNA sequencing with chain terminating inhibitors. Proceedings of the National Academy of Sciences of the United States of America 74, 5463-5467.

Selmar, D., Lieberei, R., Biehl, B. \& Voight, J. (1987). Hevea linamarase - a nonspecific $\beta$-glycosidase. Plant Physiology 83, $557-563$.

SHIMIZU, T. \& TAGUCH, H. J. (1969). Microbial treatment of industrial wastes containing cyanide. IV. Purifications and some properties of cyanide degrading enzymes of Fusarium solani. Journal of Fermentation Technology 47, 639-643.

SmITH, D. B. \& JoHnson, K. S. (1988). Single-step purification of polypeptides expressed in Escherichia coli as fusions with glutathione S-transferase. Gene 67, 31-40.

SNell, F. D. \& SNell, C. T. (1954). Colorimetric Methods of Analysis, vol. 4, p. 32. London: Van Nostrand.

StalkeR, D. M., MalyJ, L. D. \& McBride, K. E. (1988). Purification and properties of a nitrilase specific for the herbicide bromoxynil and corresponding nucleotide sequence analysis of the $b x n$ gene. Journal of Biological Chemistry 263, 6310-6314.

VIEIRA, J. \& Messing, J. (1982). The pUC plasmids, an M13mp7-derived system for insertion mutagenesis and sequencing with synthetic universal primers. Gene 19, 259-268.

WAllace, R. B. \& Mryada, C. G. (1987). Oligonucleotide probes for the screening of recombinant DNA libraries. Methods in Enzymology $152,432-442$.

Wang, P., Matthews, D. E. \& Van Etten, H. D. (1992). Purification and characterization of cyanide hydratase from the phytopathogenic fungus Gloeocercospora sorghi. Archives of Biochemistry and Biophysics 298, 569-575.

WANG, P. \& VAN ETtEN, H. D. (1992). Cloning and properties of a cyanide hydratase gene from the phytopathogenic fungus Gloeocercospora sorghi. Biochemical and Biophysical Research Communications 187, 1048-1054.

Yanisch-Perron, C., Vieira, J. \& Messing, J. (1985). Improved M13 phage cloning vectors and host strains: nucleotide sequences of the M13mp18 and pUC19 vectors. Gene 33, 103-115.

Young, R. A. \& DAvis, R. W. (1983a). Efficient isolation of genes by using antibody probes. Proceedings of the National Academy of Sciences of the United States of America 80, 1194-1198.

Young, R. A. \& Davis, R. W. (1983b). Yeast polymerase II genes: isolation with antibody probes. Science 222, 778-782.

ZeRvos, C. \& CoRDES, E. M. (1971). Mercaptoethanol catalysis for hydrolysis of $N$-benzyl-3-cyanopyridinium bromide. A model for the nitrilase reaction. Journal of Organic Chemistry 36, 1661-1667. 